\title{
KOMPENSASI DAN PENGEMBANGAN KARIR BERPENGARUH TERHADAP KEPUASAN KERJA DAN RETENSI KARYAWAN BPR LESTARI
}

\author{
Cokorda Alit Wirayudha ${ }^{1}$ \\ I Gusti Ayu Dewi Adnyani ${ }^{2}$ \\ ${ }^{1,2}$ Fakultas Ekonomi dan Bisnis Universitas Udayana (Unud), Bali, Indonesia \\ email: cokalit58@gmail.com
}

\begin{abstract}
ABSTRAK
Retensi karyawan dalam suatu perusahaan atau instansi digambarkan dengan adanya kompensasi, pengembangan karir dan kepuasan kerja. Kompensasi dan pengembangan karir yang diberikan akan meningkatkan kepuasan kerja sehingga timbul rasa untuk tinggal lebih lama dalam perusahaan. Tujuan penelitian adalah untuk mengetahui pengaruh kompensasi dan pengembangan karir terhadap kepuasan kerja dan retensi karyawan. Penelitian ini dilakukan di BPR Lestari Teuku Umar Denpasar. Sampel sebanyak 83 orang melalui Simple Random sampling. Pengumpulan data melalui wawancara dan kuesioner. Teknik analisis yang digunakan adalah analisis jalur. Kompensasi dan pengembangan karir berpengaruh positif dan signifikan terhadap kepuasan kerja. Kompensasi, pengembangan karir dan kepuasan kerja berpengaruh positif dan signifikan terhadap retensi karyawan. kepuasan kerja memediasi pengaruh kompensasi terhadap retensi karyawan, dan kepuasan kerja memediasi pengaruh pengembangan karir terhadap retensi karyawan. ketika kompensasi dan pengembangan karir yang diperoleh oleh karyawan meningkatkan kepuasan kerja, maka kepuasan kerja yang dirasakan oleh karyawan menjadi semakin kuat sehingga berpotensi meningkatkan retensi karyawan.
\end{abstract}

Kata kunci : kompensasi, pengembangan karir, kepuasan kerja, retensi karyawan.

\begin{abstract}
Employee retention in a company or institution is illustrated by compensation, career development and job satisfaction. Compensation and career development provided will increase job satisfaction so that there is sense of staying longer in the company. The purpose of this study was to determine the effect of compensation and career development on job satisfaction and employee retention. This research conducted at BPR Lestari Teuku Umar Denpasar. The sample were 83 people through Simple Random Sampling. Data collection through interviews and questionnaires. Path analysis is used. Career compensation and development have positive effect on job satisfaction. Compensation, career development and job satisfaction have positive impact on employee retention. Jo satisfaction mediates effect of compensation on employee retention, and job satisfaction mediates effect of career development on employee retention. When compensation and career development obtained by employees increase job satisfaction so that it has the potential to increase employee retention.

Keywords: compensation, career development, job satisfaction, employee retention
\end{abstract}




\section{PENDAHULUAN}

SDM merupakan salah satu penentu keberhasilan perusahaan karena peran sumber daya manusia sebagai aset berharga adalah merencanakan, melaksanakan serta mengendalikan berbagai kegiatan operasional perusahaan. Permasalahan yang muncul ketika salah dalam mengelola sumber daya manusia adalah penurunan kinerja karyawan (Albu et al., 2017). Kinerja karyawan memiliki peranan penting bagi perusahaan, apabila kinerja yang ditampilkan karyawan rendah maka akan mengakibatkan perusahaan dalam mencapai tujuan menjadi terhambat. Dengan kehilangan karyawan berarti akan memperburuk keadaan suatu perusahaan maka dari itu perlu adanya retensi karyawan.

Tabel 1.

Tingkat Turnover BPR Lestari Teuku Umar Denpasar Tahun 2018

\begin{tabular}{lllll}
\hline Bulan & $\begin{array}{l}\text { Karyawan } \\
\text { Masuk (orang) }\end{array}$ & $\begin{array}{l}\text { Karyawan } \\
\text { Keluar (orang) }\end{array}$ & $\begin{array}{l}\text { Jumlah } \\
\text { Karyawan } \\
\text { (orang) }\end{array}$ & $\begin{array}{l}\text { Labour } \\
\text { Turnover } \\
\text { (persen) }\end{array}$ \\
\hline Januari & 20 & 5 & 363 & 6,9 \\
Februari & 7 & 6 & 378 & 3,4 \\
Maret & 24 & 2 & 379 & 6,7 \\
April & 17 & 5 & 401 & 5,5 \\
Mei & 27 & 15 & 413 & 10,2 \\
Juni & 12 & 8 & 417 & 4,8 \\
Juli & 14 & 0 & 431 & 3,3 \\
Agustus & 36 & 3 & 464 & 8,4 \\
September & 26 & 9 & 481 & 7,3 \\
Oktober & 20 & 8 & 493 & 5,8 \\
November & 21 & 13 & 501 & 6,8 \\
Desember & 11 & 14 & 498 & 5,1 \\
\hline
\end{tabular}

Sumber: Data Diolah, 2019

Berdasarkan hasil wawancara dengan salah satu manajer SDM BPR Lestari Teuku Umar Denpasar menghadapi permasalahan di bidang retensi karyawan. Tabel 1. berikut ini menguraikan tingginya tingkat labour turnover pada BPR Lestari Teuku Umar Denpasar pada tahun 2018. Pada Tabel 1. dapat dilihat bahwa terdapat labour turnover yang cukup tinggi di BPR Lestari Teuku Umar Denpasar. Tingkat labour turnover tertinggi terjadi pada bulan mei sebesar 10,2 persen dan tergolong tinggi.

Retensi karyawan merupakan upaya untuk mempertahankan karyawan di dalam organisasi. Retensi karyawan mengacu pada berbagai kebijakan dan praktik yang mengarahkan karyawan agar bertahan di organisasi untuk jangka waktu yang lebih lama (Swambawa Putra, 2016). Jika retensi karyawan mampu dilaksanakan dengan baik oleh perusahaan maka pekerjaan yang dilakukan oleh karyawan akan maksimal. Retensi karyawan dapat membantu mengurangi pemborosan dalam hal tenaga, waktu dan biaya yang dikeluarkan perusahaan untuk mempekerjakan dan melatih karyawan baru. Mencegah keluarnya karyawan yang mempunyai keahlian dalam perusahaan merupakan tujuan retensi karyawan. Sa'diyah \& Faida (2018) menyatakan bahwa tingginya retensi karyawan akan mempengaruhi kinerja organisasi dalam mencapai suatu tujuan dan misi organisasi. 
Biason (2017) mengatakan kepuasan kerja adalah salah satu faktor yang mempengarui retensi karyawan, karena semakin tingginya tingkat kepuasan kerja maka akan lebih rendahnya niat untuk keluarnya karyawan. selain kepuasan kerja , kompensasi adalah faktor berikutnya yang mempengaruhi retensi karyawan. Lubis (2015) menyatakan bahwa kompensasi merupakan hal yang sangat penting bagi karyawan sebagai individu, karena upah merupakan suatu ukuran nilai atau karya mereka diantara para karyawan itu sendiri, keluarga, dan masyarakat. Kompensasi yang diberikan perusahaan akan mampu meningkatkan kepuasan kerja karyawan dan dapat memacu partisipasi karyawan sehingga para karyawan dapat bekerja dengan penuh tanggung jawab dan memiliki partisipasi kerja terhadap perusahaan. Selain kompensasi, melalui adanya pengembangan karir akan dapat meningkatkan tingkat retensi kepuasan kerja karyawan dan retensi karyawan. Pengembangan karir dapat dilakukan jika perusahaan dapat secara terbuka untuk memberikan kesempatan kepada karyawan untuk mengembangkan karirnya. Pengembangan karir memberikan kesempatan untuk pelatihan, promosi jabatan dan pengembangan keterampilan guna meningkatkan kerja karyawan dalam suatu organisasi (Syaputra et al., 2016).

Hasil wawancara sementara terhadap salah satu manajer SDM dan 5 orang karyawan yang bekerja pada BPR Lestari Teuku Umar Denpasar, mereka menyatakan bahwa terdapat niat karyawan untuk bertahan di dalam perusahaan sangat tinggi. Faktor - faktor seperti kompensasi dan pengembangan karir merupakan peran penting dalam meningkatkan kepuasan kerja dan mendorong karyawan untuk tetap berada di BPR Lestari Teuku Umar Denpasar. Hal ini dapat dilihat dari beberapa keluhan yang muncul dari karyawan, seperti misalnya : jarangnya insentif yang diterima karyawann saat mereka melakukan pekerjaan tambahan, hubungan antara atasan dan bawahan terkadang terjadi kecanggungan, serta dukungan untuk menapaki jenjang karir dalam organisasi..

Dasar teori yang digunakan pada penelitian ini adalah teori atribusi. Menurut Pesireron (2016), teori yang menyangkut tentang retensi yaitu teori atribusi. Teori ini mengarah pada bagaimana seseorang menjelaskan penyebab perilaku orang lain atau dirinya sendiri yang disebabkan pihak internal misalnya sifat, karakter dan sikap sedangkan untuk pihak eksternal seperti tekanan situasi atau keadaan tertentu yang akan memberikan pengaruh terhadap perilaku individu dalam hidupnya. Teori atribusi juga ditentukan oleh penyebab perilaku yang terdiri dari penyebab internal (dispositional attributions) dan penyebab eksternal (situational attributions). Dispositional attributions atau penyebab internal mengacu pada aspek perilaku individual yang ada dalam diri seseorang seperti kepribadian, kondisi psikis, kondisi emosional hingga persasaan positif yang timbul. Dalam penelitian ini, yang termasuk penyebab internal adalah kepuasan kerja. Sedangkan situational attributions yang mengacu pada lingkungan sekitar yang dapat mempengaruhi perilaku seperti kebiasaan organisasi, besaran kompensasi, hingga kondisi sosial setempat dalam penelitian ini yang termasuk penyebab eksternal adalah kompensasi dan pengembangan karir.

Darma \& Supriyanto (2017) mengatakan variabel kompensasi merupakan salah satu variabel yang berpengaruh signifikan terhadap kepuasan kerja. Mabaso \& Dlamini (2017) mengungkapkan kompensasi berpengaruh signifikan terhadap 
kepuasan kerja pegawai, semakin baik kompensasi yang diterima oleh seorang pegawai, maka akan semain baik pula kepuasan kerjanya.

$\mathrm{H}_{1}$ : Kompensasi berpengaruh positif dan signifikan terhadap kepuasan kerja

Menurut Lisdiani \& Ngatno (2017) berpendapat bahwa pengembangan karir memberikan keuntungan yang jelas bagi pegawai yaitu berupa kepuasan kerja dan kehidupan kerja yang berkualitas. Menurut Rahayu et al. (2019), Pengembangan karir berpengaruh signifikan terhadap kepuasan kerja. Beberapa penelitian telah dilakukan berkaitan antara pengembangan karir dan kepuasan kerja. Winda et al. (2017) mengemukakan adanya pengaruh positif pengembangan karir terhadap kepuasan kerja.

$\mathrm{H}_{2}$ : Pengembangan karir berpengaruh positif dan signifikan terhadap kepuasan kerja

Sistem upah yang efisien mempengaruhi karyawan untuk tingal lebih lama, karena jika kompensasinya yang didapatkan sesuai dengan pekerjaanya maka karyawan tersebut akan tinggal lebih lama. Penelitian yang dilakukan oleh Swambawa Putra (2016), menjelaskan apabila kompensasi yang tinggi maka retensi karyawan meningkat. Haider et al. (2015) menemukan bahwa kompensasi memiliki hubungan positif dengan retensi karyawan. Palwasha et al. (2016) menemukan bahwa kompensasi sebagai faktor penting yang mempengaruhi niat karyawan untuk tinggal.

$\mathrm{H}_{3}$ : Kompensasi berpengaruh positif dan signifikan terhadap retensi karyawan.

Penelitian yang dilakukan oleh Sitati et al. (2016) menemukan bahwa pengembangan karir secara signifika mempengaruhi retensi karyawan di Vodafone Ghana Limited. Al-sharafi (2018) menyatakan bahwa pengembangan karir berperan penting dalam organisasi akan menyebabkan peningkatan niat karyawan untuk meninggalkan organisasi. Organisasi harus mendukung karyawan untuk membuat komitmen jangka panjang kepada karyawan melalui peningkatan program pelatihan dan pengembangan karir. Penelitian yang dilakukan oleh Nagarathanam (2018) menemukan bahwa pengembangan karir meningkatkan retensi karyawan terhadap perusahaan.

$\mathrm{H}_{4}$ : Pengembangan karir berpengaruh positif dan signifikan terhadap retensi karyawan.

Penelitian yang dilakukan oleh Biason (2017) mengatakan bahwa berpengaruh siginifikan hubungan antara kepuasan kerja terhadap retensi karyawan, karena semakin tingginya tingkat kepuasan kerja maka akan lebih rendahnya niat untuk keluarnya karyawan. Oleh karena itu kepuasan kerja faktor terpenting yang harus diperhatikan. Motlou et al. (2016) menemukan bahwa kepuasan kerja berpengaruh terhadap retensi karyawan, karena ketika karyawan merasa puas terhadap pekerjaannya maka meningkatkan tingkat retensi.

$\mathrm{H}_{5}$ : Kepuasan Kerja berpengaruh positif dan signifikan terhadap retensi karyawan.

Kompensasi kepada karyawan akan memberikan kepuasan kerja tersendiri untuk karyawan, apabila seorang karyawan mendapat kompensasi yang pantas atas apa yang sudah dikerjakan pada perusahaan maka karyawan tersebut juga akan mendapat kepuasan kerja yang baik sehingga menimbulkan niat karyawan untuk tinggal lebih lama dalam perusahaan. Swambawa Putra (2016), menyatakan bahwa kompensasi berpangaruh positif terhadap retensi karyawan. Hasil penelitian 
ini sejalan dengan penelitian yang dilakukan oleh Butarbutar \& Inrawan (2015), diketahui bahwa kompensasi berpengaruh positif terhadap retensi karyawan $\mathrm{H}_{6}$ : Kepuasan Kerja memediasi pengaruh kompensasi terhadap retensi karyawan.

Penelitian yang dilakukan Poerbaningtyas (2015), yang berjudul analisis pengaruh pengembangan karir dan kepuasan kerja terhadap retensi karyawan pada PT.NET Mediatama Indonesia dengan menggunakan 80 orang sebagai sampel dengan hasil yang diperoleh bahwa pengembangan karir berpengaruh signifikan terhadap retensi karyawan. Pratiwi \& Sriathi (2017) dan Riana \& Dewi (2019) menyatakan bahwa pengembangan karir berpengaruh positif dan signifikan terhadap retensi karyawan. Hal ini menunjukkan bahwa pentingnya pengembangan karir yang diberikan terhadap karyawan maka semakin tinggi kepuasan kerja dan retensi karyawan dalam perusahaan. Hasil penelitian dari Suwandana (2018) menyatakan bahwa peluang pengembangan karir secara positif meningkatkan kepuasan karyawan untuk tinggal di organisasi.

$\mathrm{H}_{7}$ : Kepuasan Kerja memediasi pengaruh pengembangan karir terhadap retensi karyawan.

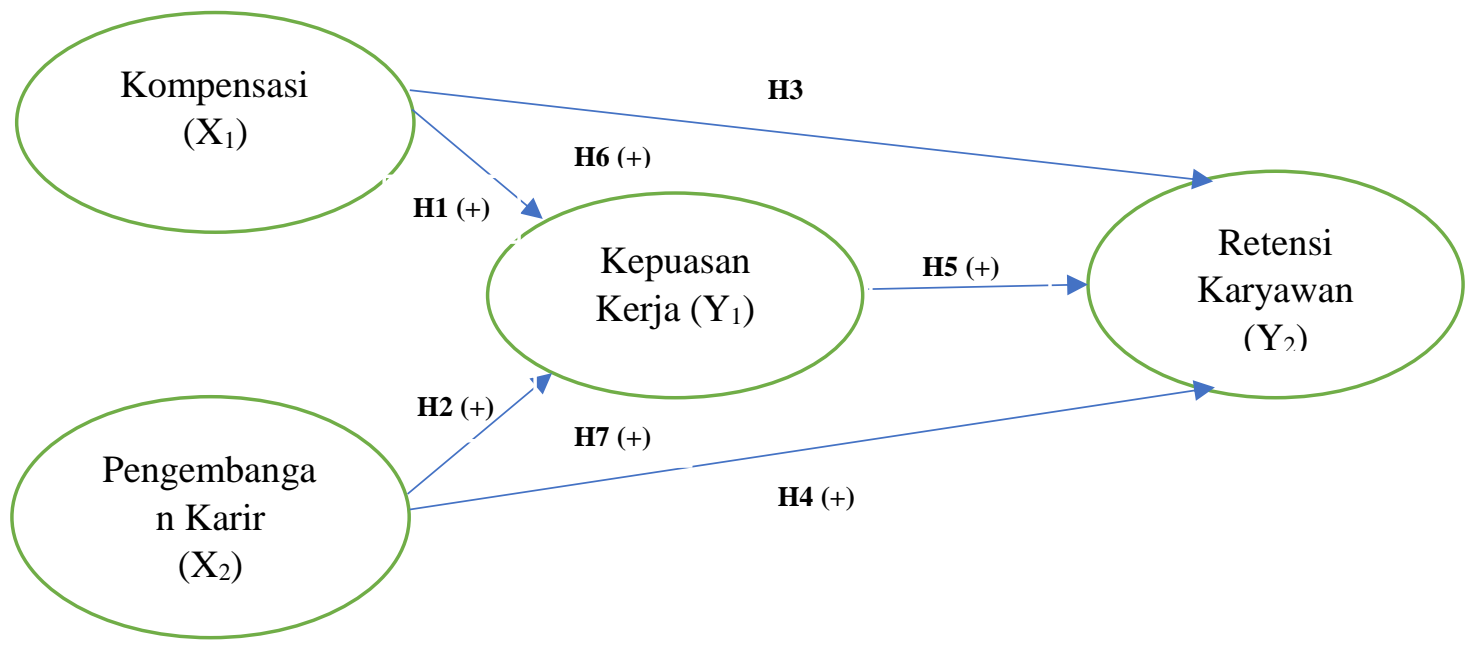

Gambar 1. Kerangka Konseptual

\section{METODE PENELITIAN}

Penelitian ini menggunakan pendekatan kuantitatif yang bersifat asosiatif. Lokasi penelitian bertempat di BPR Lestari Teuku Umar Denpasar. Alasan yang melatar belakangi peneliti melakukan penelitian ini yaitu adanya masalah retensi karyawan, kepuasan karyawan, kompensasi dan pengembangan karir di BPR Lestari Teuku Umar Denpasar.

Retensi karyawan dalam penelitian ini memiliki tiga indikator yang digunakan untuk mengukur tingkat retensi karyawan antara lain: Peluang karir organisasi, kesempatan belajar dan pengembangan diri ditempat kerja bisa menjadi kunci untuk karyawan tetap pada perusahaan. Diukur dari persepsi responden tersedianya peluang karir meningkatkan retensi karyawan di BPR Lestari Teuku Umar Denpasar, Penghargaan yang diberikan, karyawan akan tetap tinggal 
di perusahaan jika mendapatkan kompensasi atas pekerjaannya. Diukur dari persepsi responden kompensasi yang diberikan meningkatkan tingkat retensi pada BPR Lestari Teuku Umar Denpasar, Hubungan karyawan, karyawan akan bertahan ketika rekan kerja tidak pernah bertindak diskriminatif di dalam organisasi. Diukur dari persepsi responden hubungan yang baik antara karyawan meningkatkan retensi karyawan di BPR Lestari Teuku Umar Denpasar.

Kepuasan kerja dalam penelitian ini memiliki indikator untuk mengukur kepuasan kerja adalah (Puangyoykeaw \& Nishide, 2015) sebagai berikut : Pekerjaan itu sendiri adalah seberapa besar pekerjaan itu dapat memberikan kepuasan bagi pekerja itu sendiri. Diukur dari persepsi responden pekerjaan yang dilakukan sesuai dengan kemampuan karyawan pada BPR Lestari Teuku Umar Denpasar, Atasan merupakan kemampuan untuk memberikan arahan serta motivasi kepada karyawan. Diukur dari persepsi responden atasan mampu memberikan arahan serta motivasi pada BPR Lestari Teuku Umar Denpasar, Rekan kerja yaitu pola interaksi yang terjalin dengan baik antar individu dengan rekan kerja dalam suatu organisasi. Diukur dari persepsi responden memiliki hubungan yang baik dengan rekan kerja pada BPR Lestari Teuku Umar Denpasar dan Promosi adalah kesempatan setiap karyawan untuk dapat menaikan jenjang karirnya. Diukur dari persepsi responden atasan memberikan peluang untuk memberikan promosi karyawan pada BPR Lestari Teuku Umar Denpasar.

Kompensasi dalam penelitian ini merupakan bentuk penghargaan yang diberikan kepada karyawan sebagai balas jasa atau kontribusi yang mereka berikan kepada organisasinya. Adapun indikator yang digunakan untuk mengukur kompensasi adalah sebagai berikut : Gaji yang diukur dari persepsi responden mendapatkan gaji tepat waktu akan meningkatkan tingkat retensi pada BPR Lestari Teuku Umar Denpasar, Insentif yang diukur dari persepsi responden mendapatkan penghasilan tambahan jika memenuhi target BPR Lestari Teuku Umar Denpasar, Tunjangan yang diukur dari persepsi responden mendapatkan tunjangan yang diberikan sesuai dengan pekerjaan pada BPR Lestari Teuku Umar Denpasar dan Fasilitas yang diukur dari persepsi responden fasilitas yang diberikan sesuai dengan pekerjaan pada BPR Lestari Teuku Umar Denpasar

Pengembangan karir diukur melalui Indikator-indikator yang berkaitan dengan pengembangan karir adalah sebagai berikut : Perlakuan yang adil dalam berkarir adalah suatu sikap yang memberikan kesempatan yang sama kepada karyawan untuk mengembangkan karirnya. Diukur dari persepsi responden atasan memberikan perlakuan yang adil pada setiap karyawan di BPR Lestari Teuku Umar Denpasar, Kepedulian atasan adalah perilaku yang mendukung hasil kerja dan perkembangan karir karyawannya melalui umpan balik kepada karyawan. Diukur dari persepsi responden selalu mendapat dukungan dari atasan untuk mengembangkan karir di BPR Lestari Teuku Umar Denpasar, Kompetensi adalah kemampuan yang dimiliki karyawan sesuai dengan bidang yang dikuasai. Diukur dari persepsi responden keyakinan terhadap kemampuan yang dimiliki untuk meningkatkan diri pada BPR Lestari Teuku Umar Denpasa, Minat untuk dipromosikan adalah keinginan karyawan untuk meraih sasaran karir yang lebih tinggi. Diukur dari persepsi responden mendapatkan informasi mengenai promosi pada BPR Lestari Teuku Umar Denpasar dan Pendidikan formal adalah latar 
belakang pendidikan yang dimiliki oleh seorang karyawan dalam suatu perusahaan. Diukur dari persepsi responden karyawan memiliki latar belakang pendidikan formal untuk mampu bekerja pada BPR Lestari Teuku Umar Denpasar

Data primer dalam penelitian ini adalah data yang dikumpulkan secara langsung dari Obyek penelitian. Data yang diperoleh dari kuesioner dan wawancara dengan beberapa karyawan BPR Lestari Teuku Umar Denpasar. Penelitian ini data sekunder diperoleh dari perusahaan yang dapat dilihat dokumentasi perusahaan, buku-buku referensi, dan informasi lain yang berhubungan dengan penelitian. Populasi dari penelitian ini adalah seluruh karyawan di BPR Lestari Teuku Umar Denpasar yang berjumlah 498 orang pada tahun 2018. jumlah sampel yang digunakan dalam penelitian ini adalah sebanyak 83 karyawan BPR Lestari Teuku Umar Denpasar. Metode yang digunakan dalam penentuan sampel adalah teknik Probability Sampling dengan Simple Random sampling,. Pengumpulan data dalam penelitian ini dilakukan dengan menggunakan metode Observasi , Wawancara dan Kuesioner.

\section{HASIL DAN PEMBAHASAN}

Tabel 2.

Karakteristik Responden

\begin{tabular}{|c|c|c|c|c|}
\hline No & Variabel & Klasifikasi & $\begin{array}{l}\text { Jumlah } \\
\text { (orang) }\end{array}$ & $\begin{array}{c}\text { Persentase } \\
(\%)\end{array}$ \\
\hline \multirow{3}{*}{1} & \multirow{3}{*}{$\begin{array}{c}\text { Jenis } \\
\text { Kelamin }\end{array}$} & Laki - Laki & 54 & 65.06 \\
\hline & & Perempuan & 29 & 34.94 \\
\hline & & Jumlah & 83 & 100 \\
\hline \multirow{3}{*}{2} & \multirow{3}{*}{ Usia } & 17-20 Tahun & 7 & 8.43 \\
\hline & & 21-30 Tahun & 53 & 63.86 \\
\hline & & $>30$ Tahun & 23 & 27.71 \\
\hline \multirow{5}{*}{3} & \multirow{5}{*}{$\begin{array}{l}\text { Pendidikan } \\
\text { terakhir }\end{array}$} & Jumlah & 83 & 100 \\
\hline & & Diploma & 19 & 22.89 \\
\hline & & S1 & 54 & 65.06 \\
\hline & & Pasca sarjana & 10 & 12.05 \\
\hline & & Jumlah & 83 & 100 \\
\hline
\end{tabular}

Sumber : Data primer diolah, 2019

Berdasarkan Tabel 2. dapat di lihat jumlah karyawan BPR Lestari Teuku Umar Denpasar yang di jadikan sampel sebanyak 83 orang. Jika di lihat dari jenis kelamin, jenis kelamin laki-laki mendominasi dalam penelitian ini dengan presentase sebesar 65,06 persen, artinya BPR Lestari Teuku Umar Denpasar lebih banyak memperkerjakan pegawai laki-laki dan sekaligus dalam menyelesaikan tugas-tugas di kantor lebih banyak melibatkan pegawai laki-laki. Jika di lihat dari usia, yang memiliki usia 21-30 tahun mendominasi dengan presentase sebesar 63,86 persen, artinya usia tersebut masih dinyatakan produktif dalam menyelesaikan pekerjaan dalam perusahaan. Jika di lihat dari tingkat pendidikan yang memiliki tingkat pendiddikan terakhir S1 yang mendominasi dengan persentase sebesar 65,06 persen, artinya BPR Lestari Teuku Umar Denpasar lebih memprioritaskan karyawan dengan tingkat pendidikan S1. 
Tabel 3.

Hasil Uji Validitas

\begin{tabular}{|c|c|c|c|}
\hline No. & Variabel & Instrumen & $\begin{array}{c}\text { Pearson } \\
\text { Correlation }\end{array}$ \\
\hline \multirow{8}{*}{1.} & \multirow{8}{*}{ Kompensasi (X1) } & $\mathrm{X} 1.1$ & 0,808 \\
\hline & & $\mathrm{X} 1.2$ & 0,938 \\
\hline & & X1.3 & 0,927 \\
\hline & & $\mathrm{X} 1.4$ & 0,912 \\
\hline & & X1.5 & 0,763 \\
\hline & & X1.6 & 0,945 \\
\hline & & X1.7 & 0,905 \\
\hline & & $\mathrm{X} 2.1$ & 0,957 \\
\hline \multirow{4}{*}{2.} & \multirow{4}{*}{ Pengembangan Karir (X2) } & $\mathrm{X} 2.2$ & 0,944 \\
\hline & & $\mathrm{X} 2.3$ & 0,923 \\
\hline & & X2.4 & 0,962 \\
\hline & & X2.5 & 0,960 \\
\hline \multirow{5}{*}{3.} & \multirow{5}{*}{ Kepuasan kerja (Y1) } & $\mathrm{X} 2.6$ & 0,968 \\
\hline & & Y1.1 & 0,946 \\
\hline & & Y1.2 & 0,945 \\
\hline & & Y1.3 & 0,906 \\
\hline & & Y1.4 & 0,952 \\
\hline \multirow{3}{*}{4.} & \multirow{3}{*}{ Retensi karyawan (Y2) } & Y2.1 & 0,969 \\
\hline & & Y2.2 & 0,963 \\
\hline & & Y2.3 & 0,927 \\
\hline
\end{tabular}

Sumber : Data primer diolah, 2019

Tabel 4.

Uji Reliabilitas

\begin{tabular}{llc}
\hline No. & \multicolumn{1}{c}{ Variabel } & Cronbach's Alpha \\
\hline 1. & Kompensasi(X1) & 0,953 \\
2. & Pengembangan Karir (X2) & 0,978 \\
3. & Kepuasan kerja (Y1) & 0,951 \\
4. & Retensi karyawan (Y2) & 0,949 \\
\hline
\end{tabular}

Sumber : Data primer diolah, 2019

Hasil uji reliabilitas kompensasi (X1) adalah sebesar 0,953, pengembangan karir (X2) adalah sebesar 0,978, kepuasan kerja (Y1) adalah sebesar 0,951, dan untuk retensi karyawan (Y2) adalah sebesar 0,949 artinya keempat variabel tersebut lebih besar dari 0,6.. Hasil uji validitas kompensasi menyatakan seluruh instrument valid karena lebih besar dari 0,3

Berdasarkan Tabel 5. diketahui persepsi responden mengenai variabel Kompensasi yang memiliki rata-rata tertinggi adalah pernyataan "Saya mendapatkan gaji tepat waktu setiap bulan dan Saya mendapat tunjangan bayaran cuti tahunan.", diperoleh nilai rata-rata sebesar 3,52 yang masuk kriteria baik, ini berarti secara umum responden mendapatkan gaji tepat waktu setiap bulan dan mendapat tunjangan bayaran cuti tahunan. 
Tabel 5.

Deskripsi Jawaban Responden Terhadap Kompensasi

\begin{tabular}{|c|c|c|c|c|c|c|c|c|c|}
\hline \multirow{3}{*}{ No } & \multicolumn{9}{|c|}{ Proporsi Jawaban } \\
\hline & \multirow[t]{2}{*}{ Pernyataan } & \multicolumn{5}{|c|}{$\begin{array}{c}\text { Responden } \\
\text { (orang) }\end{array}$} & \multirow[t]{2}{*}{ Jumlah } & \multirow[t]{2}{*}{$\begin{array}{l}\text { Rata- } \\
\text { rata }\end{array}$} & \multirow[t]{2}{*}{ Kriteria } \\
\hline & & 1 & 2 & 3 & 4 & 5 & & & \\
\hline 1 & $\begin{array}{l}\text { Saya mendapatkan gaji } \\
\text { tepat waktu setiap bulan }\end{array}$ & 2 & 14 & 18 & 37 & 12 & 292 & 3.52 & Baik \\
\hline 2 & $\begin{array}{l}\text { Saya puas dengan gaji } \\
\text { yang saya terima untuk } \\
\text { tanggung jawab pekerjaan } \\
\text { saya }\end{array}$ & 7 & 15 & 7 & 48 & 6 & 280 & 3.37 & $\begin{array}{l}\text { Cukup } \\
\text { Baik }\end{array}$ \\
\hline 3 & $\begin{array}{l}\text { Saya mendapatkan insentif } \\
\text { jika memenuhi target } \\
\text { perusahaan }\end{array}$ & 9 & 14 & 5 & 47 & 8 & 280 & 3.37 & $\begin{array}{l}\text { Cukup } \\
\text { Baik }\end{array}$ \\
\hline 4 & $\begin{array}{l}\text { Saya mendapatkan } \\
\text { tunjangan hari raya setiap } \\
\text { tahun }\end{array}$ & 7 & 10 & 23 & 29 & 14 & 282 & 3.40 & $\begin{array}{l}\text { Cukup } \\
\text { Baik }\end{array}$ \\
\hline 5 & $\begin{array}{l}\text { Saya mendapat tunjangan } \\
\text { bayaran cuti tahunan. }\end{array}$ & 0 & 14 & 21 & 39 & 9 & 292 & 3.52 & Baik \\
\hline 6 & $\begin{array}{l}\text { Saya mendapat tunjangan } \\
\text { berupa dana pensiun. }\end{array}$ & 6 & 16 & 9 & 48 & 4 & 277 & 3.34 & $\begin{array}{l}\text { Cukup } \\
\text { Baik }\end{array}$ \\
\hline 7 & $\begin{array}{l}\text { Saya mendapat fasilitas } \\
\text { kesehatan }\end{array}$ & 6 & 11 & 23 & 31 & 12 & 281 & 3.39 & $\begin{array}{l}\text { Cukup } \\
\text { Baik }\end{array}$ \\
\hline \multicolumn{8}{|c|}{ Rata-rata } & 3,41 & Baik \\
\hline
\end{tabular}

Sumber : Data primer diolah, 2019

Tabel 6.

Deskripsi Jawaban Responden Terhadap Pengembangan Karir

\begin{tabular}{|c|c|c|c|c|c|c|c|c|c|}
\hline \multirow{3}{*}{ No } & \multirow{3}{*}{ Pernyataan } & \multirow{2}{*}{\multicolumn{5}{|c|}{$\begin{array}{c}\text { Proporsi Jawaban } \\
\text { Responden } \\
\text { (orang) } \\
\end{array}$}} & \multirow{3}{*}{ Jumlah } & \multirow{3}{*}{$\begin{array}{c}\text { Rata- } \\
\text { rata }\end{array}$} & \multirow{3}{*}{ Kriteria } \\
\hline & & & & & & & & & \\
\hline & & 1 & 2 & 3 & 4 & 5 & & & \\
\hline 1 & $\begin{array}{l}\text { Perusahaan memberikan } \\
\text { perlakuan yang adil pada } \\
\text { setiap karyawan dalam } \\
\text { pengembangan karir }\end{array}$ & 5 & 16 & 11 & 45 & 6 & 280 & 3.37 & $\begin{array}{l}\text { Cukup } \\
\text { Baik }\end{array}$ \\
\hline 2 & $\begin{array}{l}\text { Atasan mendukung } \\
\text { pengembangan karir } \\
\text { karyawannya }\end{array}$ & 3 & 19 & 14 & 40 & 7 & 278 & 3.35 & $\begin{array}{l}\text { Cukup } \\
\text { Baik }\end{array}$ \\
\hline 3 & $\begin{array}{l}\text { saya berkompeten } \\
\text { pekerjaan saya sekarang }\end{array}$ & 8 & 12 & 13 & 38 & 12 & 283 & 3.41 & Baik \\
\hline 4 & $\begin{array}{l}\text { Saya memiliki informasi } \\
\text { mengenai promosi } \\
\text { jabatan yang ada di } \\
\text { perusahaan }\end{array}$ & 4 & 17 & 12 & 46 & 4 & 278 & 3.35 & $\begin{array}{l}\text { Cukup } \\
\text { Baik }\end{array}$ \\
\hline 5 & $\begin{array}{l}\text { Saya berminat untuk } \\
\text { dipromosikan }\end{array}$ & 4 & 18 & 15 & 41 & 5 & 274 & 3.30 & $\begin{array}{l}\text { Cukup } \\
\text { Baik }\end{array}$ \\
\hline 6 & $\begin{array}{l}\text { Saya memiliki } \\
\text { pendidikan formal yang } \\
\text { cukup untuk bekerja di } \\
\text { perusahaan ini }\end{array}$ & 7 & 13 & 13 & 38 & 12 & 284 & 3.42 & Baik \\
\hline \multicolumn{8}{|c|}{ Rata-rata } & 3,37 & Baik \\
\hline
\end{tabular}

Sumber : Data primer diolah, 2019 
Tabel 7.

Deskripsi Jawaban Responden Terhadap Kepuasan Kerja

\begin{tabular}{|c|c|c|c|c|c|c|c|c|c|}
\hline \multirow{3}{*}{ No } & \multirow{3}{*}{ Pernyataan } & \multicolumn{5}{|c|}{ Proporsi Jawaban } & \multirow{3}{*}{ Jumlah } & \multirow{3}{*}{$\begin{array}{c}\text { Rata- } \\
\text { rata }\end{array}$} & \multirow{3}{*}{ Kriteria } \\
\hline & & \multicolumn{5}{|c|}{$\begin{array}{c}\begin{array}{c}\text { Responden } \\
\text { (orang) }\end{array} \\
\end{array}$} & & & \\
\hline & & 1 & 2 & 3 & 4 & 5 & & & \\
\hline 1 & $\begin{array}{l}\text { Pekerjaan yang saya } \\
\text { kerjakan sangat menarik atau } \\
\text { sesuai dengan kepribadian } \\
\text { saya }\end{array}$ & 2 & 22 & 12 & 34 & 13 & 283 & 3.41 & Puas \\
\hline 2 & $\begin{array}{l}\text { Saya puas dengan adanya } \\
\text { dukungan atasan saya }\end{array}$ & 2 & 19 & 13 & 37 & 12 & 287 & 3.46 & Puas \\
\hline 3 & $\begin{array}{l}\text { Saya memiliki hubungan } \\
\text { yang baik dengan rekan kerja }\end{array}$ & 6 & 16 & 14 & 35 & 12 & 280 & 3.37 & $\begin{array}{l}\text { Cukup } \\
\text { Puas }\end{array}$ \\
\hline \multirow[t]{2}{*}{4} & $\begin{array}{l}\text { Adanya kesempatan untuk } \\
\text { memneroleh promosi }\end{array}$ & 0 & 24 & 12 & 36 & 11 & 283 & 3.41 & Puas \\
\hline & \multicolumn{6}{|c|}{ Rata-rata } & & 3,41 & Puas \\
\hline
\end{tabular}

Sumber : Data primer diolah, 2019

Tabel 8.

Deskripsi Jawaban Responden Terhadap Retensi Karyawan

\begin{tabular}{|c|c|c|c|c|c|c|c|c|c|}
\hline \multirow{3}{*}{ No } & \multirow{3}{*}{ Pernyataan } & \multirow{2}{*}{\multicolumn{5}{|c|}{$\begin{array}{c}\text { Proporsi Jawaban } \\
\text { Responden } \\
\text { (orang) }\end{array}$}} & \multirow{3}{*}{ Jumlah } & \multirow{3}{*}{$\begin{array}{l}\text { Rata- } \\
\text { rata }\end{array}$} & \multirow{3}{*}{ Kriteria } \\
\hline & & & & & & & & & \\
\hline & & 1 & 2 & 3 & 4 & 5 & & & \\
\hline 1 & $\begin{array}{l}\text { Saya bertahan karena } \\
\text { perusahaan menyediakan } \\
\text { peluang karir yang sama } \\
\text { bagi setiap karyawan. }\end{array}$ & 5 & 16 & 11 & 38 & 13 & 287 & 3.46 & Tinggi \\
\hline 2 & $\begin{array}{l}\text { Saya bertahan karena } \\
\text { perusahaan selalu } \\
\text { memberikan kompensasi } \\
\text { atas kinerja yang } \\
\text { diselesaikan. }\end{array}$ & 7 & 14 & 7 & 44 & 11 & 287 & 3.46 & Tinggi \\
\hline 3 & $\begin{array}{l}\text { Saya bertahan karena } \\
\text { rekan kerja tidak pernah } \\
\text { bertindak diskriminatif }\end{array}$ & 0 & 21 & 14 & 34 & 14 & 290 & 3.49 & Tinggi \\
\hline \multicolumn{8}{|c|}{ Rata-rata } & 3,47 & Tinggi \\
\hline
\end{tabular}

Sumber : Data primer diolah, 2019

Berdasarkan Tabel 6. diketahui persepsi responden mengenai variabel pengembangan karir yang memiliki rata-rata tertinggi adalah pernyataan "Saya memiliki latar belakang pendidikan formal yang cukup untuk mampu bekerja di perusahaan ini", diperoleh nilai rata-rata sebesar 3,42 yang masuk kriteria baik, ini berarti secara umum responden memiliki latar belakang pendidikan formal yang cukup untuk mampu bekerja di perusahaan ini.

Berdasarkan Tabel 7. diketahui persepsi responden mengenai variabel kepuasan kerja yang memiliki rata-rata tertinggi adalah pernyataan "Saya puas dengan adanya dukungan atasan saya", diperoleh nilai rata-rata sebesar 3,46 yang masuk kriteria puas, ini berarti secara umum responden puas dengan adanya dukungan atasan mereka. 
Berdasarkan Tabel 8. diketahui persepsi responden mengenai variabel retensi karyawan yang memiliki rata-rata tertinggi adalah pernyataan "Saya bertahan karena rekan kerja tidak pernah bertindak diskriminatif", diperoleh nilai rata-rata sebesar 3,49 yang masuk kriteria tinggi, ini berarti secara umum responden bertahan karena rekan kerja tidak pernah bertindak diskriminatif

Tabel 9.

Hasil Analisis Jalur Pada Struktur 1

\begin{tabular}{|c|c|c|c|c|c|}
\hline \multirow[t]{2}{*}{ Model } & \multicolumn{2}{|c|}{ Unstandardized Coefficients } & \multirow{2}{*}{$\begin{array}{c}\begin{array}{c}\text { Standardized } \\
\text { Coefficients }\end{array} \\
\text { Beta }\end{array}$} & \multirow[t]{2}{*}{$\mathbf{t}$} & \multirow[t]{2}{*}{ Sig. } \\
\hline & B & Std. Error & & & \\
\hline (Constant) & 0.922 & 0.346 & & 2.663 & 0.009 \\
\hline Kompensasi & 0.410 & 0.112 & 0.398 & 3.648 & 0.000 \\
\hline Pengembangan Karir & 0.318 & 0.108 & 0.321 & 2.948 & 0.004 \\
\hline
\end{tabular}

Sumber : Data primer diolah, 2019

Variabel Kompensasi pada Tabel 9. memiliki koefisien sebesar 0,398 berarti Kompensasi memiliki pengaruh positif terhadap kepuasan kerja, ini diartikan apabila Kompensasi meningkat maka kepuasan kerja akan meningkat sebesar 0,398. Variabel pengembangan karir memiliki koefisien sebesar 0,321 berarti pengembangan karir memiliki pengaruh positif terhadap kepuasan kerja, ini diartikan apabila pengembangan karir meningkat maka kepuasan kerja akan meningkat sebesar 0,321 .

Tabel 10.

Hasil Analisis Jalur Pada Struktur 2

\begin{tabular}{|c|c|c|c|c|c|}
\hline \multirow{2}{*}{ Model } & \multicolumn{2}{|c|}{$\begin{array}{l}\text { Unstandardized } \\
\text { Coefficients }\end{array}$} & \multirow{2}{*}{$\begin{array}{c}\text { Standardized } \\
\text { Coefficients }\end{array}$} & \multirow[t]{2}{*}{$\mathbf{t}$} & \multirow[t]{2}{*}{ Sig. } \\
\hline & B & Std. Error & & & \\
\hline (Constant) & 0.305 & 0.328 & & 0.931 & 0.355 \\
\hline Kompensasi & 0.239 & 0.110 & 0.223 & 2.169 & 0.033 \\
\hline Pengembangan Karir & 0.355 & 0.103 & 0.345 & 3.445 & 0.001 \\
\hline Kepuasan Kerja & 0.327 & 0.103 & 0.314 & 3.167 & 0.002 \\
\hline $\mathrm{R}^{2} \quad: 0.563$ & & & & & \\
\hline
\end{tabular}

Sumber : Data primer diolah, 2019

Variabel Kompensasi memiliki koefisien sebesar 0,223 berarti Kompensasi memiliki pengaruh positif terhadap retensi karyawan, ini diartikan apabila Kompensasi meningkat maka retensi karyawan akan meningkat sebesar 0,223. Variabel pengembangan karir memiliki koefisien sebesar 0,345 berarti pengembangan karir memiliki pengaruh positif terhadap retensi karyawan, ini diartikan apabila pengembangan karir meningkat maka retensi karyawan akan meningkat sebesar 0,345. Variabel kepuasan kerja memiliki koefisien sebesar 0,314 berarti kepuasan kerja memiliki pengaruh positif terhadap retensi karyawan 
, ini diartikan apabila kepuasan kerja meningkat maka retensi karyawan akan meningkat sebesar 0,314 .

Pada perhitungan nilai koefisien determinasi total didapatkan sebesar 0,744, maka kesimpulannya adalah $74,4 \%$ variabel retensi karyawan BPR Lestari Teuku Umar Denpasar dipengaruhi oleh Kompensasi, pengembangan karir dan kepuasan kerja, sedangkan sisanya 25,6 \% dipengaruhi oleh faktor lain yang tidak dimasukkan dalam model penelitian atau diluar model penelitian.

Tabel 11.

Uji Normalitas (One-Sample Kolmogorov-Smirnov)

\begin{tabular}{ll}
\hline Persamaan & Kolmogorov-Smirnov Z \\
\hline Substruktur 1 & 0,080 \\
Substruktur 2 & 0,146 \\
\hline
\end{tabular}

Berdasarkan uji normalitas dengan menggunakan One-Sample KolmogorovSmirnov Test yang ditampilkan pada Tabel 11. tersebut menunjukkan bahwa besarnya nilai Kolmogorov-Smirnov adalah sebesar 0,080 dan 0,146 mengindikasikan bahwa data yang digunakan pada penelitian ini terdistribusi normal

Berdasarkan Tabel 12. tersebut ditunjukkan bahwa tidak terdapat variabel bebas yang memiliki nilai tolerance kurang dari 0,10 Maka dari pada itu model regresi bebas dari gejala multikoleniaritas.

Tabel 12.

Uji Multikolinieritas (Tolerance and Variance Inflation Factor)

\begin{tabular}{|c|c|c|c|}
\hline & \multirow{2}{*}{ Model } & \multicolumn{2}{|c|}{ Collinearity Statistics } \\
\hline & & Tolerance & $V I F$ \\
\hline \multirow{2}{*}{ Substruktur1 } & Kompensasi & 0.639 & 1.565 \\
\hline & Pengembangan Karir & 0.639 & 1.565 \\
\hline \multirow{3}{*}{ Substruktur2 } & Kompensasi & 0.545 & 1.836 \\
\hline & Pengembangan Karir & 0.574 & 1.742 \\
\hline & Kepuasan Kerja & 0.585 & 1.710 \\
\hline
\end{tabular}

Sumber : Data primer diolah, 2019

Tabel 13.

Uji Heteroskedastisitas (Uji Glejser)

\begin{tabular}{clcl}
\hline Persamaan & \multicolumn{1}{c}{ Model } & T & Sig. \\
\hline \multirow{2}{*}{ Substruktur1 } & Kompensasi & 1.179 & 0.132 \\
& Pengembangan Karir & -1.146 & 0.135 \\
\multirow{2}{*}{ Substruktur 2 } & Kompensasi & 1.179 & 0.117 \\
& Pengembangan Karir & -1.196 & 0.115 \\
& Kepuasan Kerja & 0.110 & 0.913 \\
\hline
\end{tabular}

Sumber : Data primer diolah, 2019 
Berdasarkan Tabel 13. tersebut, ditunjukkan bahwa masing-masing model memiliki nilai signifikansi lebih besar dari 5\%. Hal ini menunjukkan bahwa variabel bebas yang digunakan pada penelitian ini tidak berpengaruh secara signifikan terhadap variabel terikatnya yaitu absolute error, maka dari itu, penelitian ini bebas dari gejala heteroskedastisitas.

Kompensasi memiliki nilai Beta sebesar 0,398 dan nilai Sig. sebesar 0,000, maka dapat dikatakan $\mathrm{H}_{1}$ diterima karena nilai Sig. 0,000<0,05. Kesimpulannya adalah bahwa Kompensasi memiliki pengaruh positif dan signifikan terhadap kepuasan kerja, dengan kata lain semakin meningkat Kompensasi BPR Lestari Teuku Umar Denpasar, maka semakin meningkat kepuasan kerja BPR Lestari Teuku Umar Denpasar. Sehingga hipotesis pertama diterima. Pengembangan karir memiliki nilai Beta sebesar 0,321 dan nilai Sig. sebesar 0,004, maka dapat dikatakan $\mathrm{H}_{2}$ diterima karena nilai Sig. 0,004 $<0,05$. Kesimpulannya adalah bahwa pengembangan karir memiliki pengaruh positif dan signifikan terhadap kepuasan kerja, dengan kata lain semakin meningkat pengembangan karir BPR Lestari Teuku Umar Denpasar, maka semakin meningkat kepuasan kerja BPR Lestari Teuku Umar Denpasar . Sehingga hipotesis kedua diterima.

Kompensasi memiliki nilai Beta sebesar 0,223 dan nilai Sig. sebesar 0,033, maka dapat dikatakan $\mathrm{H}_{3}$ diterima karena nilai Sig. $0,033<0,05$. Kesimpulannya adalah Kompensasi berpengaruh positif dan signifikan terhadap retensi karyawan dengan kata lain semakin meningkat Kompensasi maka retensi karyawan BPR Lestari Teuku Umar Denpasar akan semakin meningkat. Pengembangan karir memiliki nilai Beta sebesar 0,345 dan nilai Sig. sebesar 0,001, maka dapat dikatakan $\mathrm{H}_{4}$ diterima karena nilai Sig. 0,001 < 0,05. Kesimpulannya adalah pengembangan karir berpengaruh positif dan signifikan terhadap retensi karyawan dengan kata lain semakin meningkat pengembangan karir maka retensi karyawan BPR Lestari Teuku Umar Denpasar akan semakin meningkat. Sehingga hipotesis peempat diterima.

Kepuasan kerja memiliki nilai Beta sebesar 0,314 dan nilai Sig. sebesar 0.002, maka dapat dikatakan $\mathrm{H}_{5}$ diterima karena nilai Sig. $0.002<0,05$. Kesimpulannya adalah bahwa Kepuasan kerja memiliki pengaruh positif dan signifikan terhadap retensi karyawan, dengan kata lain apabila kepuasan kerja meningkat maka retensi karyawan BPR Lestari Teuku Umar Denpasar. akan semakin meningkat. Sehingga hipotesis kelima diterima.

Tabel 14.

Pengaruh Langsung, Pengaruh Tidak Langsung Kompensasi (X1), Pengembangan Karir (X2), Terhadap Kepuasan Kerja (Y1) dan Retensi Karyawan (Y2)

\begin{tabular}{lccc}
\hline \multicolumn{1}{c}{ Pengaruh variabel } & $\begin{array}{c}\text { Pengaruh } \\
\text { langsung }\end{array}$ & $\begin{array}{c}\text { Pengaruh tidak } \\
\text { langsung melalui Y1 }\end{array}$ & Pengaruh Total \\
\hline $\mathrm{X} 1 \rightarrow \mathrm{Y} 1$ & 0,398 & & 0,398 \\
$\mathrm{X} 2 \rightarrow \mathrm{Y} 1$ & 0,321 & & 0,321 \\
$\mathrm{Y} 1 \rightarrow \mathrm{Y} 2$ & 0,314 & 0,125 & 0,314 \\
$\mathrm{X} 1 \rightarrow \mathrm{Y} 2$ & 0,223 & 0,101 & 0,348 \\
$\mathrm{X} 2 \rightarrow \mathrm{Y} 2$ & 0,345 & & 0,446 \\
\hline Sumber $:$ Data primer diolah, 2019 & &
\end{tabular}


Pada penelitian yang dilakukan di BPR Lestari Teuku Umar Denpasar tentang pengaruh Kompensasi terhadap kepuasan kerja, maka didapatkan hasil Kompensasi memiliki pengaruh langsung terhadap kepuasan kerja dengan persentase sebesar 0,398 atau 39,8\%, artinya apabila Kompensasi meningkat maka kepuasan kerja akan meningkat sebesar 39,8\%. Pada penelitian yang dilakukan di BPR Lestari Teuku Umar Denpasar tentang pengaruh pengembangan karir terhadap kepuasan kerja, maka didapatkan hasil pengembangan karir memiliki pengaruh langsung terhadap kepuasan kerja dengan persentase sebesar 0,321 atau 32,1\%, artinya apabila pengembangan karir meningkat maka kepuasan kerja akan meningkat sebesar 32,1\%. Pada penelitian yang dilakukan BPR Lestari Teuku Umar Denpasar tentang pengaruh Kompensasi terhadap retensi karyawan, maka didapatkan hasil Kompensasi memiliki pengaruh langsung terhadap retensi karyawan dengan persentase sebesar 0,223 atau 22,3\%, artinya apabila kompensasi meningkat maka retensi karyawan akan meningkat sebesar 22,3\%. Pada penelitian yang dilakukan di BPR Lestari Teuku Umar Denpasar tentang pengaruh pengembangan karir terhadap retensi karyawan , maka didapatkan hasil pengembangan karir memiliki pengaru langsung terhadap retensi karyawan dengan persentase sebesar 0,345 atau $34,5 \%$, artinya apabila pengembangan karir meningkat maka retensi karyawan akan meningkat sebesar $34,5 \%$.

Pada penelitian yang dilakukan di BPR Lestari Teuku Umar Denpasar tentang pengaruh kepuasan kerja terhadap retensi karyawan, maka didapatkan hasil kepuasan kerja memiliki pengaruh langsung terhadap retensi karyawan dengan persentase sebesar 0,314 atau 31,4\%, artinya apabila kepuasan kerja meningkat maka retensi karyawan akan meningkat sebesar 31,4\%. Pada penelitian yang dilakukan BPR Lestari Teuku Umar Denpasar .tentang peran kepuasan kerja dalam memediasi pengaruh Kompensasi terhadap retensi karyawan, maka didapatkan hasil bahwa Kompensasi memiliki pengaruh langsung dan tidak langsung melalui kepuasan kerja terhadap retensi karyawan dengan nilai koefisien masing-masing sebesar 0,223 dan 0,125 , sehingga besaran pengaruh totalnya adalah 0,348 atau $34,8 \%$, artinya apabila kompensasi dimediasi oleh kepuasan kerja maka retensi karyawan akan meningkat sebesar $34,8 \%$

Pada penelitian yang dilakukan di BPR Lestari Teuku Umar Denpasar tentang peran kepuasan kerja dalam memediasi pengaruh pengembangan karir terhadap retensi karyawan, maka didapatkan hasil bahwa pengembangan karir memiliki pengaruh langsung dan tidak langsung melalui kepuasan kerja terhadap retensi karyawan dengan nilai koefisien masing-masing sebesar 0,345 dan 0,101, sehingga besaran pengaruh totalnya adalah 0,446 atau $44,6 \%$, artinya apabila pengembangan karir dimediasi oleh kepuasan kerja maka retensi karyawan akan meningkat sebesar 44,6\%.

Berdasarkan hasil Uji Sobel menunjukkan bahwa hasil tabulasi $\mathrm{Z}=$ 2,263>1,96 yang berarti variabel Kompensasi berpengaruh positif dan signifikan terhadap Retensi karyawan BPR Lestari Teuku Umar Denpasar dengan mediasi Kepuasan kerja, sehingga kepuasan kerja merupakan variabel mediasi pengaruh antara Kompensasi terhadap Retensi karyawan BPR Lestari Teuku Umar Denpasar, Sehingga hipotesis keenam diterima. Berdasarkan hasil Uji Sobel 
menunjukkan bahwa hasil tabulasi $\mathrm{Z}=2,072>1,96$ yang berarti variabel pengembangan karir berpengaruh positif dan signifikan terhadap Retensi karyawan BPR Lestari Teuku Umar Denpasar dengan mediasi Kepuasan kerja, sehingga kepuasan kerja merupakan variabel mediasi pengaruh antara pengembangan karir terhadap Retensi karyawan BPR Lestari Teuku Umar Denpasar, Sehingga hipotesis ketujuh diterima.

Nilai VAF (35,9 persen) diantara 20 persen hingga 80 persen, maka dapat dikategorikan sebagai pemediasi parsial (partial mediation), maka dapat disimpulkan untuk efek mediasi yang dihasilkan untuk kepuasan kerja memediasi pengaruh kompensasi terhadap retensi karyawan adalah memediasi secara parsial. Nilai VAF (22,6 persen) diantara 20 persen hingga 80 persen, maka dapat dikategorikan sebagai pemediasi parsial (partial mediation), maka dapat disimpulkan untuk efek mediasi yang dihasilkan untuk kepuasan kerja memediasi pengaruh Pengembangan karir terhadap retensi karyawan adalah memediasi secara parsial.

Hasil hipotesis dalam penelitian ini menunjukkan bahwa Kompensasi memiliki pengaruh positif dan signifikan terhadap kepuasan kerja, dengan kata lain semakin meningkat Kompensasi BPR Lestari Teuku Umar Denpasar, maka semakin tinggi tingkat kepuasan kerja BPR Lestari Teuku Umar Denpasar. Sehingga hipotesis pertama diterima. Hal ini sejalan dengan hasil penelitian yang dilakukan oleh Darma \& Supriyanto (2017) mengatakan variabel kompensasi merupakan salah satu variabel yang berpengaruh signifikan terhadap kepuasan kerja. Mabaso \& Dlamini (2017) mengungkapkan kompensasi berpengaruh signifikan terhadap kepuasan kerja pegawai, semakin baik kompensasi yang diterima oleh seorang pegawai, maka akan semain baik pula kepuasan kerjanya.

Hasil hipotesis dalam penelitian ini menunjukkan bahwa pengembangan karir memiliki pengaruh positif dan signifikan terhadap kepuasan kerja, dengan kata lain semakin meningkat pengembangan karir BPR Lestari Teuku Umar Denpasar, maka semakin tinggi tingkat kepuasan kerja BPR Lestari Teuku Umar Denpasar. Sehingga hipotesis kedua diterima. Hal ini sejalan dengan hasil penelitian yang dilakukan oleh Winda et al. (2017) dan Hafid Jusuf et al. (2016) mengemukakan adanya pengaruh positif pengembangan karir terhadap kepuasan kerja.

Hasil hipotesis dalam penelitian ini menunjukkan bahwa Kompensasi berpengaruh positif dan signifikan terhadap retensi karyawan dengan kata lain semakin meningkat Kompensasi maka retensi karyawan BPR Lestari Teuku Umar Denpasar akan semakin meningkat. Sehingga hipotesis ketiga diterima. Hal ini sejalan dengan hasil penelitian yang dilakukan oleh Swambawa Putra (2016), menjelaskan apabila kompensasi yang tinggi maka retensi karyawan meningkat. Haider et al. (2015), menemukan bahwa kompensasi berkontribusi untuk meningkatkan retensi karyawan. Palwasha et al. (2016), menemukan bahwa kompensasi sebagai faktor penting yang mempengaruhi niat karyawan untuk tinggal.

Hasil hipotesis dalam penelitian ini menunjukkan bahwa pengembangan karir berpengaruh positif dan signifikan terhadap retensi karyawan dengan kata lain semakin meningkat pengembangan karir maka retensi karyawan BPR Lestari Teuku Umar Denpasar akan semakin meningkat.Sehingga hipotesis keempat 
diterima. Hal ini sejalan dengan hasil penelitian yang dilakukan oleh Sitati et al. (2016) menemukan bahwa pengembangan karir secara signifikan mempengaruhi retensi karyawan di Hotel Kenya. Al-sharafi (2018) menyatakan bahwa pengembangan karir berperan penting dalam organisasi akan menyebabkan peningkatan niat karyawan untuk meninggalkan organisasi. Nagarathanam (2018) menemukan bahwa pengembangan karir meningkatkan retensi karyawan terhadap perusahaan.

Hasil hipotesis dalam penelitian ini menunjukkan bahwa Kepuasan kerja memiliki pengaruh positif dan signifikan terhadap retensi karyawan, dengan kata lain apabila kepuasan kerja meningkat maka retensi karyawan BPR Lestari Teuku Umar Denpasar. akan semakin meningkat. Sehingga hipotesis kelima diterima. Hasil penelitian ini sesuai dengan penelitian yang dilakukan oleh Biason (2017) mengatakan bahwa berpengaruh siginifikan hubungan antara kepuasan kerja terhadap retensi karyawan, karena semakin tingginya tingkat kepuasan kerja maka akan lebih rendahnya niat untuk keluarnya karyawan. Motlou et al. (2016), menemukan bahwa kepuasan kerja berpengaruh terhadap retensi karyawan, karena ketika karyawan merasa puas terhadap pekerjaannya maka meningkatkan tingkat retensi

Hasil hipotesis dalam penelitian ini menunjukkan bahwa Kompensasi berpengaruh positif dan signifikan terhadap Retensi karyawan BPR Lestari Teuku Umar Denpasar dengan mediasi Kepuasan kerja, sehingga kepuasan kerja merupakan variabel mediasi pengaruh antara Kompensasi terhadap Retensi karyawan BPR Lestari Teuku Umar Denpasar, Sehingga hipotesis keenam diterima. Hasil penelitian ini sejalan dengan Swambawa Putra (2016), menyatakan bahwa kompensasi berpangaruh positif terhadap retensi karyawan. Hasil penelitian ini sejalan dengan penelitian yang dilakukan oleh Butarbutar \& Inrawan (2015), diketahui bahwa kompensasi berpengaruh positif terhadap retensi karyawan.

Hasil hipotesis dalam penelitian ini menunjukkan bahwa pengembangan karir berpengaruh positif dan signifikan terhadap Retensi karyawan BPR Lestari Teuku Umar Denpasar dengan mediasi Kepuasan kerja, sehingga kepuasan kerja merupakan variabel mediasi pengaruh antara pengembangan karir terhadap Retensi karyawan BPR Lestari Teuku Umar Denpasar, Sehingga hipotesis ketujuh diterima.

Hasil penelitian ini sejalan dengan Poerbaningtyas (2015), yang berjudul analisis pengaruh pengembangan karir dan kepuasan kerja terhadap retensi karyawan pada PT.NET Mediatama Indonesia dengan menggunakan 80 orang sebagai sampel dengan hasil yang diperoleh bahwa pengembangan karir berpengaruh signifikan terhadap retensi karyawan.. Pratiwi \& Sriathi (2017) dan Riana \& Dewi (2019) menyatakan bahwa pengembangan karir berpengaruh positif dan signifikan terhadap retensi karyawan. Hal ini menunjukkan bahwa pentingnya pengembangan karir yang diberikan terhadap karyawan maka semakin tinggi kepuasan kerja dan retensi karyawan dalam perusahaan. Hasil penelitian dari Bhojak \& Shakdwipee (2015) menyatakan bahwa peluang pengembangan karir secara positif meningkatkan kepuasan karyawan untuk tinggal di organisasi.

Implikasi teoritis dari hasil penelitin ini memberikan bukti pada pengembangan ilmu perilaku keorganisasian dan sumber daya manusia khususnya 
mengenai kompensasi, pengembangan karir, kepuasan kerja dan retensi karyawan. Selain itu hasil penelitian ini secara praktis dapat menjadi salah satu acuan bagi peneliti lainnnya yang ingin meneliti mengenai kompensasi, pengembangan karir, kepuasan kerja dan retensi karyawan. Secara teoritis penelitian ini juga memberikan pemahaman bahwa kompensasi, pengembangan karir dan kepuasan kerja secara nyata dapat meningkatkan retensi karyawan, ketika kompensasi, dan pengembangan karir yang diperoleh oleh karyawan meningkatkan kepuasan kerja, maka kepuasan kerja yang dirasakan oleh karyawan menjadi semakin kuat sehingga berpotensi meningkatkan retensi karyawan.

Ada beberapa hal yang menjadi keterbatasan dalam penelitian ini, yakni terbatasnya jurnal dan sumber variabel mediasi yang digunakan dalam penelitian sehingga mempengaruhi jadwal dan target penelitian yang ditetapkan. Keterbatasan lain dalam penelitian ini yakni beberapa responden tidak mengisi kuesioner dengan lengkap, seperti pengisian identitas responden dan jawaban kuesioner yang kurang lengkap, namun hal ini dapat diatasi dengan menyebarkan kuesioner melebihi jumlah sampel yang telah ditargetkan, agar kuesioner yang tidak lengkap dapat digantikan dengan kuesioner lainnya.

\section{SIMPULAN}

Kompensasi berpengaruh positif dan signifikan terhadap kepuasan kerja BPR Lestari Teuku Umar Denpasar sehingga hipotesis 1 diterima. Hal ini menunjukkan bahwa jika kompensasi semakin meningkat maka kepuasan kerja akan meningkat pula. Pengembangan karir berpengaruh positif dan signifikan terhadap kepuasan kerja BPR Lestari Teuku Umar Denpasar sehingga hipotesis 2 diterima. Hal ini menunjukkan bahwa jika pengembangan karir semakin meningkat maka kepuasan kerja akan meningkat pula. Kompensasi berpengaruh positif dan signifikan terhadap retensi karyawan BPR Lestari Teuku Umar Denpasar sehingga hipotesis 3 diterima. Hal ini menunjukkan bahwa jika kompensasi semakin meningkat maka retensi karyawan akan meningkat pula.

Pengembangan karir berpengaruh positif dan signifikan terhadap retensi karyawan BPR Lestari Teuku Umar Denpasar sehingga hipotesis 4 diterima. Hal ini menunjukkan bahwa jika pengembangan karir semakin meningkat maka retensi karyawan akan meningkat pula. Kepuasan kerja berpengaruh positif dan signifikan terhadap retensi karyawan BPR Lestari Teuku Umar Denpasar sehingga hipotesis 5 diterima. Hal ini menunjukkan bahwa jika kepuasan kerja semakin meningkat maka retensi karyawan akan meningkat pula. Kepuasan kerja merupakan variabel mediasi pengaruh antara Kompensasi terhadap Retensi karyawan BPR Lestari Teuku Umar Denpasar. sehingga hipotesis 6 diterima. Hal ini menunjukkan bahwa kepuasan kerja mampu memediasi kompensasi terhadap retensi karyawan. Kepuasan kerja merupakan variabel mediasi pengaruh antara pengembangan karir terhadap Retensi karyawan BPR Lestari Teuku Umar Denpasar sehingga hipotesis 7 diterima. Hal ini menunjukkan bahwa kepuasan kerja mampu memediasi pengembangan karir terhadap retensi karyawan.

Berdasarkan hasil yang diperoleh Kompensasi, pengembangan karir dan kepuasan kerja memiliki pengaruh yang positif signifikan terhadap keputusan 
retensi karyawan BPR Lestari Teuku Umar Denpasar, ini menunjukan bahwa semakin tinggi Kompensasi, pengambangan karir dan kepuasan kerja akan dapat meningkatkan keputusan dalam melakukan retensi karyawan BPR Lestari Teuku Umar Denpasar. Pihak BPR Lestari Teuku Umar Denpasar harus tetap mempertahankan Kompensasi dan pengembangan karir di dalam perusahaan agar karyawan merasa terdorong dalam meningkatkan semangat dalam bekerja, sehingga akan meningkatkan retensi karyawan BPR Lestari Teuku Umar Denpasar. Dalam segi kompensasi indikator yang memiliki rata-rata terendah adalah Saya mendapat tunjangan berupa dana pensiun, hal yang harus dilakukan perusahaan adalah memberikan tunjangan berupa dana pensiun secara merata kepada karyawan, atau fasilitas yang diberikan haruslah memadai. Dalam segi pengembangan karir indikator yang memiliki rata-rata terendah adalah Saya berminat untuk dipromosikan atasan, hal yang harus dilakukan perusahaan adalah memberikan promosi jabatan kepada karyawan agar karyawan merasa semangat dalam bekerja. Dalam segi kepuasan kerja indikator yang memiliki rata-rata terendah adalah Saya memiliki hubungan yang baik dengan rekan kerja, hal yang harus dilakukan oleh perusahaan adalah membuat lingkungan kerja yang nyaman agar karyawan merasa puas, dan tidak memihak dalam menyelesaikan masalah antara karyawan.

\section{REFERENSI}

Al-sharafi, H. (2018). The Effect of Training and Career Development on Employees Retention -A Study on the Telecommunication Organizations in Yemen. The Journal of Social Sciences Research, 1(2), 420-430. https://doi.org/10.32861/jssr.spi2.420.430

Albu, R. G., Mandru, L., \& Suciu, T. (2017). Impact of ethics upon business success. International Business Information Management, 1(11), 203-211.

Bhojak, Y., \& Shakdwipee, P. (2015). A Study of Employee Satisfaction with Special Reference to " Manufacturing Industries ." International Journal of Modern Communication Technologies \& Research (IJMCTR), 2(8), 22-28.

Biason, R. S. (2017). The Effect of Job Satisfaction to Employee Retention: Saint Louis Univeristy, Baguio City. Journal of Business and Management Review, 1(4), 1-10. https://doi.org/10.13140/RG.2.2.27677.72161

Butarbutar, M., \& Inrawan, A. (2015). Pengaruh Kompensasi Terhadap Retensi Karyawan Pada Toko Harum Manis Pematangsiantar. Maker, 1(2), 1-20.

Darma, P. S., \& Supriyanto, A. S. (2017). the Effect of Compensation on Satisfaction and Employee Performance. Management and Economics Journal (MEC-J), 1(1), 66. https://doi.org/10.18860/mec-j.v1i1.4524

Hafid Jusuf, A., Mallongi, S., \& Latief, B. (2016). The effect of career development, leadership style and organizational culture on job satisfaction and organizational commitment. International Journal of Business and Management Invention, 5(3), 2319. https://doi.org/10.19030/jabr.v32i3.9667 
Haider, M., Rasli, A., Shoaib, A., Yusoff, C., Mohammesd, R. Bin, Malik, M. M., ... Tariq, F. (2015). The Impact of Human Resource Practices on Employee Retention in the Telecom Sector. International Journal of Economics and Financial Issues, 5(1), 63-69.

Lisdiani, V., \& Ngatno, N. (2017). Pengaruh Pengembangan Karir Terhadap Kepuasan Kerja Karyawan Melalui Motivasi Kerja Sebagai Variabel Intervening (Studi Kasus Pada Hotel Grasia Semarang). Jurnal Ilmu Administrasi Bisnis, 6(4), 105-112.

Lubis, R. (2015). Pengaruh Kompensasi, Lingkungan Kerja Dan Desain Tugas Terhadap Kepuasan Kerja Dan Dampaknya Terhadap Retensi Karyawan PMI. Jurnal Manajemen, 4(1), 164-173.

Mabaso, C. M., \& Dlamini, B. I. (2017). Impact of Compensation and Benefits on Job Satisfaction. Research Journal of Business Management, 11(1), 80-90.

Motlou, R., Singh, S., \& Karodia, A. M. (2016). An Evaluation of The Impact of Job Satisfaction On Employee Retention At Lonmin Rowland Shaft North West Province. Arabian Journal of Business an Management Review, 5(10), $15-49$.

Nagarathanam, R. (2018). the Impact of Career Development Practices on Employees ' the Impact of Career Development Practices on Employee S ' Retention in Qatar Aviation Industry. ASCENT International Conference Proceeding - Accounting and Business Management, 1(12), 325-330.

Palwasha, B., Ashfaq, A., \& Abdul, H. M. (2016). The Moderating Role of Work Environment On the Relationship Between Compensation, Job Security, and Employee Retention. International Journal of Economic Perspective, 10(4), 726-738.

Pesireron, S. (2016). Pengaruh Keterampilan, Job Stress Dan Disiplin Kerja Terhadap Kinerja Auditor Inspektorat (Study Empiris Pada Inspektorat Kabupaten Seram Bagian Timur Dan Kabupaten Maluku Tengah). Jurnal Maneksi, 5(1), 1-20.

Poerbaningtyas, L. S. (2015). Analisis Pengaruh Pengembangan Karir dan Kinerja Karyawan Terhadap Retensi Karyawan pada Divisi Produksi PT. NET Mediatama Indonesia. Jurnal Bina Nusantara, 1(1), 12.

Pratiwi, L. P. Y. A., \& Sriathi, A. A. A. (2017). Pengaruh Lingkungan Kerja Dan Pengembangan Karir Terhadap Retensi Karyawan Pada Hotel Santika Nusa Dua Bali. E-Jurnal Manajemen Universitas Udayana, 6(3), 1478-1506.

Puangyoykeaw, K., \& Nishide, Y. (2015). Is there a link between compensation packages and job performance in the Ghana police service. Journal of Business Management, 7(44), 43.

Rahayu, M., Rasid, F., \& Tannady, H. (2019). The Effect of Career Training and Development on Job Satisfaction and its Implications for the Organizational 
Commitment of Regional Secretariat (SETDA) Employees of Jambi Provincial Government. International Review of Management and Marketing, 9(1), 79-89.

Riana, I, G., \& Dewi, K, E, O. (2019). Pengaruh Pengembangan Karir, Kompensasi Dan Komitmen Organisasional Terhadap Retensi Karyawan Pada Bintang Kuta Hotel. E-Jurnal Manajemen Universitas Udayana, 8(2), 7836-7862.

Sa'diyah, H., \& Faida, A. I. (2018). Pengaruh Employee Retention Dan Turnover Intention Terhadap Kinerja Karyawan Melalui Kepuasan Kerja . Jurnal Trunojoyo, 1(1), 34-65. Retrieved from http://www.exmba.buu.ac.th/Research/Bkk/Ex-23-Bkk/51721286/

Sitati, N., Were, S., \& Waititu, G. A. (2016). Effects of Career Development on Employee Retention in Hotels in Kenya. Business and Change Management, 3(4), 940-955.

Suwandana, I. G. M. (2018). Employee Career Development: A Study On Career Management, Competence, Satisfaction And Organizational Commitment In A Star Hotel Of Bali. RJOAS, 10(82), 1-20.

Swambawa Putra, I. B. (2016). Pengaruh Kompensasi, Lingkungan Kerja, dan Percieved Organizational Support (POS) Terhadap Retensi Kerja. E-Jurnal Manajemen Unud, 5(2), 829-830.

Syaputra, A., Wasnury, R., \& Rama, R. (2016). Pengaruh Loyalitas Kerja Dan Pelatihan Kerja Terhadap Peningkatan Produktivitas Kerja Karyawan Pada Perusahaan Daerah Air Minum (Pdam) Tirta Siak Kota Pekanbaru. Jurnal Online Mahasiswa Fakultas Ekonomi Universitas Riau, 4(1), 125-139.

Winda, O., Nayati, U. H., \& Arik, P. (2017). Impact of Compensation and Career Development on Job Satisfaction. RJOAS, 4(4), 113-119. https://doi.org/https://doi.org/10.18551/rjoas.2017-04.15 